\title{
Essential oil from Euphorbia esula inhibits proliferation and induces apoptosis in HepG2 cells via mitochondrial dysfunction
}

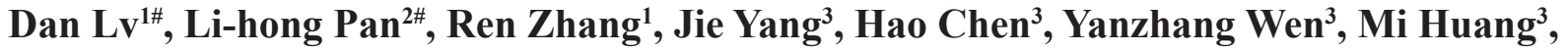 \\ Xinhua Ma ${ }^{\oplus 3}$, Qiang Wang ${ }^{* *}$, Xinzhou Yang ${ }^{3 *}$

\begin{abstract}
${ }^{1}$ Institute of Infection, Immunology and Tumor Microenviroment, Hubei Province Key Laboratory of Occupational Hazard Identification and Control, Medical College, Wuhan University of Science and Technology, Wuhan, China, ${ }^{2}$ College of Basic Medicine and Forensic Medicine of Hangzhou Medical College, ${ }^{3}$ School of Pharmaceutical Sciences, South-Central University for Nationalities, Wuhan, China
\end{abstract}

\begin{abstract}
Hepatocellular carcinoma is one of the most prevalent malignancies and a leading cause of cancer-related mortality worldwide. However, the therapies to prevent hepatocellular carcinoma are still limited and the emergence of drug resistance leads to the development of new anti-cancer drugs and combinational chemotherapy regimens. Our study was aimed to explore the anticancer effects of the essential oil extract (EEEO) from Euphorbia esula which has been widely used in traditional Chinese folk medicine and possessed potential cytotoxic effects in several human tumor cells. However, the mechanisms of EEEOinduced anti-proliferation and apoptosis have not been completely elucidated. In this study, EEEO was prepared by hydro-distillation and the main chemical component of EEEO was identified by GC-MS. HepG2 cells were treated with EEEO in vitro and then evaluated with respect to proliferation, apoptosis, and levels of reactive oxygen species (ROS) and apoptotic proteins. Our studies showed that EEEO decreased cell viability, elevated ROS levels, and induced apoptosis of HepG2 cells in a concentrationand time-dependent manner. Furthermore, Bcl-2 was down-regulated, while Bax was up-regulated in HepG2 after EEEO treatment. These results suggest that EEEO induced apoptosis of HepG2 cells and indicate that this apoptosis might be mediated by the mitochondrial pathway.
\end{abstract}

Keywords: Euphorbia esula. Hepatocellular carcinoma. Apoptosis. Reactive oxygen species. Mitochondrial pathway.

\section{INTRODUCTION}

Hepatocellular carcinoma (HCC), the most common primary malignant tumor of the liver, has become a serious threat to human health worldwide (Santos et al., 2015; Lv et al., 2017). China has the highest incidence and mortality of liver cancer in the world. It is estimated that $55 \%$ of liver cancer cases occurred in China alone compared to the rest of the developing countries in 2010 (Wei et al., 2014). Surgery, chemotherapy and radiotherapy are the three most common strategies used for the treatment of HCC (Hong et al., 2015). Although

\footnotetext{
*Correspondence: Q. Wang. Institute of Infection Immunology and Tumor Microenviroment, Hubei Province Key Laboratory of Occupational Hazard Identification and Control, Medical College, Wuhan University of Science and Technology, Wuhan 430065, China. E-mail: wangqiang@wust.edu.cn X.Z. Yang. School of Pharmaceutical Sciences, South-Central University for Nationalities, Wuhan, China. E-mail: xzyang@mail.scuec.edu.cn. ${ }^{*}$ Authors contributed equally to this work.
}

drug therapy remains the mainstay in the treatment of liver cancer, traditional chemotherapy drugs in clinical application currently suffer from lack of selectivity and wide distribution in the body. As a result, these drugs often produce toxic side effects including severe systemic effects, such as myelosuppression (leukopenia, immune suppression, fatigue), digestive tract epithelial cell toxicity (nausea and vomiting) and hair cell toxicity (hair loss), affecting the efficacy of chemotherapy (Li, Ling, 2012). Therefore, identification of novel anticancer agents with high therapeutic effects but less toxic effects has become a key issue in the search for innovative drugs for the treatment of HCC (Song et al., 2015a).

Euphorbia esula is a perennial herbaceous plant of Euphorbiaceae (Chen, Gilbert, 2006). It grows in the hillside, valley grassland, and sandy ground, reaching about $30 \sim 60 \mathrm{~cm}$ in height, and is widely distributed in China (Ernst et al., 2015). It has long been used for the 
treatment of swollen limbs, difficulty in urination, enteritis, malaria, and chronic tracheitis in clinical practice. In addition, E. esula has been shown to have a good topical curative effect on cervical lymphoid tuberculosis, ringworm sores, and itching. As a traditional Chinese folk medicine, E. esula was generally used for the treatment of swelling and warts, but seldom used for the treatment of malignant tumors, especially in hepatocellular carcinoma.

In this study, we report that EEEO has the potential to induce apoptosis in HCC cells. In addition, we also identified 13 chemical components from E. esula by GC-MS analysis, validated the potential anti-HCC effects of EEEO in vitro, and elucidated its likely anti-HCC mechanism through the mitochondrial pathway.

\section{MATERIAL AND METHODS}

\section{Material and equipment}

Dulbecco's Modified Eagle Medium (DMEM) and fetal bovine serum (FBS) were purchased from Life Technologies Corporation (USA). 3-(4,5-dimethylthiazol2-yl)-2,5-diphenyltetrazoliunbromide (MTT) and dimethyl sulphoxide (DMSO) were obtained from Sigma (USA). The antibodies for Bcl-2, Bax, Caspase-3, Caspase-9, and $\beta$-actin were obtained from Cell Signaling Technology (USA). Cell Apoptosis PI Detection Kit was purchased from BD Pharmingen (China). Protein assay kits (BCA) and reactive oxygen species (ROS) were bought from Beyotime Biotechnology (China). The chemical reagents were purchased from Sinopharm Chemical Reagent Co. Ltd. (China). The HPLC grade methanol and acetonitrile were purchased from Tedia (USA). Enzyme standard instrument was purchased from American Bio Rad 3550.

\section{Plant material and preparation of EEEO}

The whole plants of Euphorbia esula were collected on 16 August, 2013 in Wufeng County, Hubei province, China, and identified by Professor Dingrong Wan at School of Pharmaceutical Sciences, South-Central University for Nationalities (SCUN), Wuhan, China. A voucher Specimen (No. SC0034) is deposited in the Herbarium of School of Pharmaceutical Sciences, SCUN. Air-dried whole plants of E. esula ( $450 \mathrm{~g})$ were boiled with distilled water $(3 \times 3500 \mathrm{~mL}, 3 \mathrm{~h}$ each $)$ to yield crude essential oil in a $3 \mathrm{~L}$ round bottom flask fitted with a volatile oil distillation apparatus (Yang et al., 2016). The obtained residue was extracted with cyclohexane, then dried with anhydrous sodium sulfate and filtered to yield the EEEO
(4.7 mL). The resulting EEEO was stored at $4{ }^{\circ} \mathrm{C}$ prior to further analyses and bioassay.

\section{GC-MS analysis of EEEO}

An Agilent gas chromatography-mass spectrometer $(7890 \mathrm{~N} / 5973 \mathrm{iN})$ coupled with a HP $5975 \mathrm{C}$ mass spectrometer (Agilent Technologies, USA) and a HP-5MS capillary column $(30 \mathrm{~m} \times 0.25 \mathrm{~mm}$ id; $0.25 \mu \mathrm{m}$ film thickness) was used for the chemical analysis of EEEO (Yang et al., 2017). Helium gas was used as a carrier gas with a flow rate of $1.2 \mathrm{~mL} / \mathrm{min}$. The ionization energy was set at $70 \mathrm{eV}$ with an acquisition range between 50 and $800 \mathrm{~m} / \mathrm{z}$ and a scan rate of $1 \mathrm{scan} / \mathrm{s}$. The composition was reported as a relative percentage of the total peak area. Injector and detector temperatures were set at $250^{\circ} \mathrm{C}$ and $280^{\circ} \mathrm{C}$, respectively. The oven temperature was initially maintained at $50^{\circ} \mathrm{C}$, then increased to $150^{\circ} \mathrm{C}$ at $5{ }^{\circ} \mathrm{C} / \mathrm{min}$, and finally increased to $300^{\circ} \mathrm{C}$ at $15^{\circ} \mathrm{C} / \mathrm{min}$ with a $10 \mathrm{~min}$ hold. EEEO was dissolved in diethylether, and $0.2 \mu \mathrm{L}$ of the diluted sample was injected manually. The chemical components were identified based on the comparison of their relative retention time and their mass spectra with those in the NIST08 database.

\section{Cell culture}

Human carcinoma cell lines HepG2, Hep3B, Huh7, SMMC-7721 and normal hepatocyte cell line L0-2 were purchased from the American Type Culture Collection (ATCC, Manassas, VA). These cells were inoculated in DMEM (Gibco) with 10\% fetal bovine serum (FBS), $100 \mathrm{U} / \mathrm{mL}$ penicillin and $100 \mathrm{mg} / \mathrm{L}$ streptomycin at $37^{\circ} \mathrm{C}$ and $5 \% \mathrm{CO}_{2}$, in a humid condition.

\section{MTT assay}

Cell viability and cytotoxicity was determined using the 3-(4, 5-dimethylthiazol-2-yl)-2,5-diphenyltetrazolium bromide (MTT) assay (Stepanenko et al., 2015; Song et al., 2015 b). For the treatment, EEEO was dissolved in DMSO to make a stock solution of $200 \mathrm{mg} / \mathrm{mL}$ and further diluted to final concentrations of $0,25,50,100,150$ and $200 \mu \mathrm{g} / \mathrm{mL}$ with serum-free culture medium containing 1\%o DMSO (Li et al., 2016). The logarithmic phase cells (HepG2, Hep3B, Huh7, SMMC-7721 and L0-2) were cultured in the 96-well plates at a concentration of $1 \times 10^{5}$ cells $/ \mathrm{mL}(100 \mu \mathrm{L} /$ well $)$, and treated in triplicate with various concentration of EEEO for $24 \mathrm{~h}$. Then, $20 \mu \mathrm{L}$ $(5 \mu \mathrm{g} / \mathrm{mL}$ ) MTT was added to the original solution per well, and the cells continued to be cultured for $4 \mathrm{~h}$. After 
removing the supernatant, $150 \mu \mathrm{L}$ DMSO was added to each well and mixed thoroughly. Absorbance was recorded at $490 \mathrm{~nm}$ using a microplate reader (BIO-RAD).

\section{CCK-8 assay}

Cell viability was measured by CCK-8 assay (Beyotime, Shanghai, China) following manufacturer's instructions. Cells were cultured and treated in the same way as in the MTT assay. After the treatment, $10 \mu \mathrm{L}$ CCK-8 solution was added to each well and the plates were incubated for an additional $4 \mathrm{~h}$ at $37^{\circ} \mathrm{C}$. The absorbance at $450 \mathrm{~nm}$ was measured. The percentage of viable cells was calculated using the formula: ratio $(\%)=[\mathrm{OD}($ Treatment $)-$ OD (Blank)]/[OD (Control)-OD (Blank)] $\times 100$.

\section{Trypan blue exclusion staining}

For trypan blue exclusion assay, HepG2 cells were plated in 6-well culture plates containing DMEM medium with $10 \% \mathrm{FBS}$ and incubated at $37^{\circ} \mathrm{C}$ in $5 \% \mathrm{CO}_{2}$ for $24 \mathrm{~h}$ and allowed to reach $60-70 \%$ confluency. The cells were then treated with the concentration approximated with $\mathrm{IC}_{50}$ values of EEEO for appropriate time points $(80 \mu \mathrm{g} / \mathrm{mL}$ of EEEO for $12 \mathrm{~h}, 50 \mu \mathrm{g} / \mathrm{mL}$ of EEEO for $24 \mathrm{~h}$ and $45 \mu \mathrm{g} / \mathrm{mL}$ of EEEO for $48 \mathrm{~h}$ ). The cells were then trypsinzed and stained with trypan blue (Invitrogen, $\mathrm{CA}$ ) and the viable and dead cells counted using a hematocytometer. For every sample a total of 300 cells were counted in triplicates and the percentage of viable cells was calculated using the formula: ratio $(\%)=$ the number of non-staining cells $/ 300 \times 100$.

\section{Hoechst 33258 staining assay}

The fluorescent dye Hoechst 33258 was used to visualize the nuclear fragmentation, a characteristic of apoptotic cell death (Xu et al., 2013). The HepG2 cells were plated in 6-well culture plates containing DMEM medium with $10 \% \mathrm{FBS}$ and incubated at $37{ }^{\circ} \mathrm{C}$ in $5 \%$ $\mathrm{CO}_{2}$ for $24 \mathrm{~h}$. During post-incubation stage, the cells were treated with $0,100,150 \mu \mathrm{g} / \mathrm{mL}$ EEEO in serum-free medium for $24 \mathrm{~h}$. In addition, the cells were treated with $100 \mu \mathrm{g} / \mathrm{mL}$ EEEO for another $48 \mathrm{~h}$. After discarding the medium, cells were washed twice with PBS, and $1.0 \mathrm{~mL}$ of stationary liquid (methanol: acetic acid $=3: 1$ ) were used to fix the cells for $30 \mathrm{~min}$. And then, Hoechst 33258 solution $(5 \mu \mathrm{g} / \mathrm{mL})$ was used to stain nuclei for $30 \mathrm{~min}$. Finally, the nucleus shape changes were observed by fluorescence microscope (Leica Microsystems, Wetzlar, Germany).

\section{Flow cytometry analysis (FACS)}

The HepG2 cells $\left(1 \times 10^{5} \sim 4 \times 10^{5}\right.$ cells per well $)$ were plated into 6-well cell culture plates and exposed to different concentration of EEEO $(0,100,150 \mu \mathrm{g} / \mathrm{mL})$ for $24 \mathrm{~h}$ or $48 \mathrm{~h}$. Cells were collected by trypsinization and centrifugation, and washed with cold PBS twice (Zheng et al., 2014). Briefly, the cells were fixed with cold $80 \%$ ethanol and maintained at $4{ }^{\circ} \mathrm{C}$ for at least $18 \mathrm{~h}$. Samples were then pelleted and washed with PBS. Intracellular RNA was removed by incubating samples with $1.0 \mathrm{mg} / \mathrm{mL}$ of RNaseA at $37^{\circ} \mathrm{C}$ for $2 \mathrm{~h}$. Finally, cells were stained with $50 \mu \mathrm{g} / \mathrm{mL}$ propidium iodine (PI) and the cell cycle distribution analysis was measured using a flow cytometer (BD Biosciences, USA). Cell cycle changes were analyzed by propidium iodine staining. Cells in Sub G1 phase were considered to be apoptotic.

\section{Reactive oxygen species (ROS) levels}

The determination of ROS levels was based on the oxidation of DCFH-DA. HepG2 cells were cultivated at a density of $1 \times 10^{5}$ per well in a six-well plate for $24 \mathrm{~h}$, and incubated with $\operatorname{EEEO}(0,100,150 \mu \mathrm{g} / \mathrm{mL})$ for 12 or $24 \mathrm{~h}$. The cells were then treated with DCFH-DA $(5 \mathrm{mM})$ for $30 \mathrm{~min}$ at $37{ }^{\circ} \mathrm{C}$ in the dark (Huang et al., 2016). The cells were then washed twice and harvested in PBS. The fluorescence of DCFH-DA was detected with a flow cytometer.

\section{Western blotting assay}

HepG2 cells treated with EEEO $(0,100,150 \mu \mathrm{g} /$ $\mathrm{mL})$ were collected at different time points $(0,24$ and $48 \mathrm{~h}$ ), washed twice with ice-cold PBS, and incubated in protein lysis buffer for $30 \mathrm{~min}$ at $4{ }^{\circ} \mathrm{C}$. The lysates were centrifuged at $12000 \mathrm{x}$ g for $15 \mathrm{~min}$ at $4{ }^{\circ} \mathrm{C}$ (Feng et al., 2016). The concentrations of total lysate protein were detected by a standard Bradford assay. The protein lysates were resolved by $10 \%$ sodium dodecyl sulfatepolyacrylamide gel electrophoresis and transferred to nitrocellulose membranes (Liu et al., 2016). The nitrocellulose membranes were blocked with 5\% nonfat milk at room temperature for $2 \mathrm{~h}$ and then incubated overnight at $4{ }^{\circ} \mathrm{C}$ with primary antibodies (1: 2,000 to 1 : 4000 dilution). After washing the membranes three times for 10 min each with Tris-buffered saline containing Tween-20, they were incubated with HRP-conjugated secondary antibodies. Proteins were visualized using an Enhanced Chemiluminescence-Plus kit, which can analyze the expression of proteins in cells of the information 
through analysis of the position of coloring and color depth for a particular protein to find the target protein.

\section{Statistical analysis}

Data are expressed as the means \pm standard deviation (SD). Statistical analyses were performed using one-way analysis of variance with Graphpad prime 5.0 software. Differences were considered statistically significant at $* P<0.05,{ }^{*} P<0.01$ and ${ }^{* * *} P<0.001$ (Banafa, Roshan, 2013).

\section{RESULTS}

\section{Chemical characterization of EEEO}

EEEO was prepared by hydro-distillation technique with a yield of $0.43 \%(\mathrm{w} / \mathrm{w})$ based on the dry weight of E. esula. The main identified compounds, their percentages as well as the retention times were shown and listed in Figure 1 and Table I. In the case of E. esula, 13 different compounds were identified representing the $93.4 \%$ of the total oil. EEEO was dominant by nonacosane (19.57\%), 3 $\alpha$-cholesta-4,6-dien-3-ol (11.19\%) and pentacosane $(10.54 \%)$, followed by eicosane $(7.88 \%)$, heptacosane (7.21\%), hexacosane (6.56\%), phytol (5.78\%) and 6,10,14-trimethyl-2-peantadecanone (5.57\%). Small amounts of other chemical components were characterized as 5-hydroxy-2,4-di-t-butylphenyl pentanoic acid (4.58\%), tetracosane (4.48\%), and androst-5,7-dien-3-ol-17-one
$(4.27 \%)$ as well as 2,6,10-trimethyl-dodecane (3.54\%) and 2-(E)-decenal (2.25\%).

\section{Selective inhibition of cells proliferation by EEEO}

The effects of EEEO on proliferation of several HCC cell lines and normal liver cell line were examined by MTT assay, CCK-8 assay and trypan blue exclusion staining. In both MTT assay and CCK-8 assay, after incubating for $24 \mathrm{~h}$, viability of all HCC cell lines in EEEO treated groups were significantly inhibited in a dose-dependent manner, while EEEO treatment showed little toxic impact on normal liver cell line (L0-2). It is suggesting that EEEO inhibited proliferation of HCC. Comparison of cell viability in 4 tumor cell lines: Huh7, Hep3B, SMMC-7721 and HepG2 revealed that HepG2 cells showed the greatest sensitivity to EEEO (Figure 2A, C). Therefore, HepG2 cells were chosen as a model cell line to study mechanisms that mediate anti-HCC effects of EEEO. Based on the cell viability results, EEEO was added to 96-well plate in the concentration range of 0 to $150 \mu \mathrm{g} / \mathrm{mL}$. Following culture for 12, 24 and $48 \mathrm{~h}$, cell viability was measured by MTT assay and CCK- 8 assay and expressed as a percentage of the control $(0 \mu \mathrm{g} / \mathrm{mL}$ of EEEO served as the control group) (Figure 2B, D). Progressive increase in the length of culture time increased the inhibitory effects of EEEO on HepG2 cells. These results showed that EEEO inhibited the growth of HepG2 cells in a dose- and time-dependent manner. To directly verify the anti-proliferative effects and toxicity of EEEO, HepG2 and L0-2 cells were treated

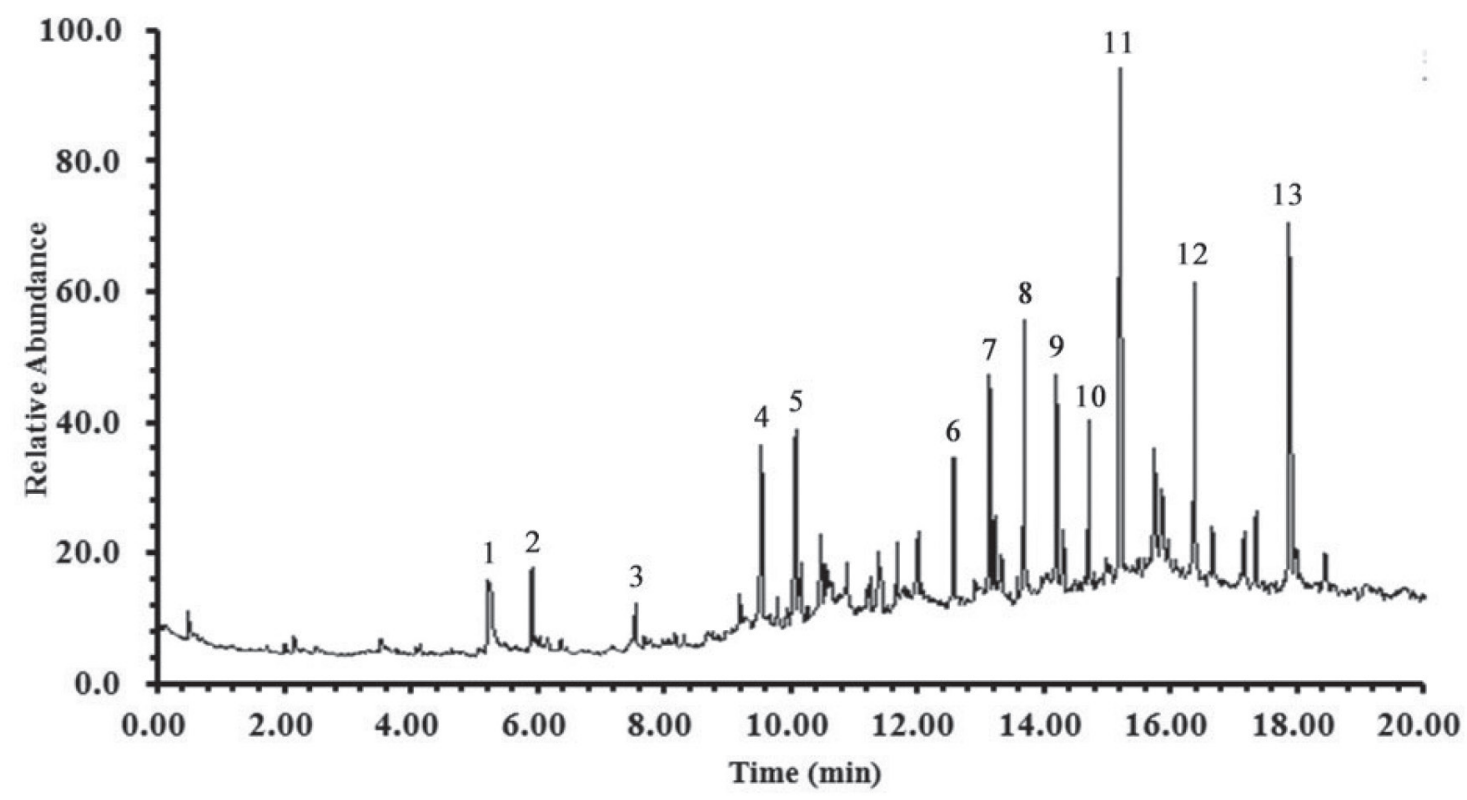

FIGURE 1 - The GC-MS analysis of EEEO is shown at different time with peak labeling corresponding to compounds 1-13. 
TABLE I - Main chemical components (\%) of EEEO

\begin{tabular}{lccc}
\hline No & Rt (min) & Compound & Percentage (\%) \\
\hline $\mathbf{1}$ & 5.21 & 2-(E)-decenal & 2.25 \\
$\mathbf{2}$ & 5.93 & 2,6,10-trimethyl-dodecane & 3.54 \\
$\mathbf{3}$ & 7.55 & 5-hydroxy-2,4-di-t-butylphenyl pentanoic acid & 4.58 \\
$\mathbf{4}$ & 9.58 & 6,10,14-trimethyl-2-peantadecanone & 5.57 \\
$\mathbf{5}$ & 10.09 & phytol & 5.78 \\
$\mathbf{6}$ & 12.48 & tetracosane & 4.48 \\
$\mathbf{7}$ & 13.20 & heptacosane & 7.21 \\
$\mathbf{8}$ & 13.61 & eicosane & 7.88 \\
$\mathbf{9}$ & 14.32 & hexacosane & 6.56 \\
$\mathbf{1 0}$ & 14.78 & androst-5,7-dien-3-ol-17-one & 4.27 \\
$\mathbf{1 1}$ & 15.20 & nonacosane & 19.57 \\
$\mathbf{1 2}$ & 16.39 & pentacosane & 10.54 \\
$\mathbf{1 3}$ & 17.97 & 3a-cholesta-4,6-dien-3-ol & 11.19 \\
\hline
\end{tabular}

Rt refers to the retention time.

with EEEO in the concentrations approximated with $\mathrm{IC}_{50}$ values, and the percentage of viable cells was measured by trypan blue exclusion staining (Figure 2E). Similar results were obtained that EEEO significantly induced HepG2 cell death with little effect on non-tumor liver cells. These results revealed that EEEO is a promising antineoplastic agent for selectively inhibiting HCC.

\section{EEEO-induced HepG2 cell apoptosis in vitro}

Further experiments using fluorescence microscopy and flow cytometry analyses were performed to determine whether EEEO promotes HepG2 cell apoptosis. Morphological analysis with Hoechst 33258 staining showed nuclear with chromatin condensation and uneven staining, chromatin marginalization, and the formation of apoptotic bodies in cells. Moreover, fluorescence was more conspicuous in cells treated with $100 \mu \mathrm{g} / \mathrm{mL}$ EEEO than those treated with $50 \mu \mathrm{g} / \mathrm{mL}$ (Figure 3A). There was a linear increase between incubation time and fluorescence (Figure 3B). To evaluate the ability of EEEO to induce cell apoptosis, HepG2 cells were treated with 50 and $100 \mu \mathrm{g} / \mathrm{mL}$ EEEO. After $24 \mathrm{~h}$, the ratio of Sub-G1 DNA to the total cell population was tested by FACS. From left to right in Figure 3C, the percentages of in Sub G1 phase cells were $0.89 \%, 27.34 \%$ and $35.01 \%$ at 0,50 and $100 \mu \mathrm{g} /$ $\mathrm{mL}$, respectively, suggesting that EEEO dose-dependently led to HepG2 cell apoptosis. Similarly, EEEO timedependently triggered HepG2 cell apoptosis (Figure 3D). These data suggested that EEEO could promote HepG2 cell apoptosis in vitro.

\section{EEEO treatment caused generation of intracellular ROS}

Reactive oxygen species (ROS) are usually generated in cells as by-products of metabolic reactions and their level is very high in cancer cells. Thus, cancer cells experience higher oxidative stress conditions and are prone to cell damage and death following an increase in endogenous ROS levels. In HepG2 cells, accumulating evidence indicates that intracellular ROS can trigger apoptosis (Mi et al., 2016). After treatment of HepG2 cell with EEEO, the histogram peak shifted from left to the right (Figure 4A and 4B). EEEO treatment was statistically significant compared to the untreated control. ROS levels increased in a dose- and time-dependent manner.

\section{Inhibition of mitochondrial pathway by EEEO treatment}

This study suggested that it is the $\mathrm{Bcl}-2 / \mathrm{Bax}$ ratio that governs apoptotic signal transduction. Since the $\mathrm{Bcl}-2 / \mathrm{Bax}$ ratio is regulated by the release of cytocrome $\mathrm{c}$ from the mitochondria, the possible involvement of the Bcl-2 family proteins in the EEEO mediated apoptosis of HepG2 cells was investigated. As shown in Figure 5, $\mathrm{Bcl}-2 / \mathrm{Bax}$ protein ratio was decreased in EEEO-treated cells compared with the control group. Furthermore, the data indicated that EEEO could significantly increase caspase-9 expression. Caspase- 9 is one of the key regulators in the mitochondrial apoptotic pathway. The activated caspase- 9 is released from mitochondria, which 


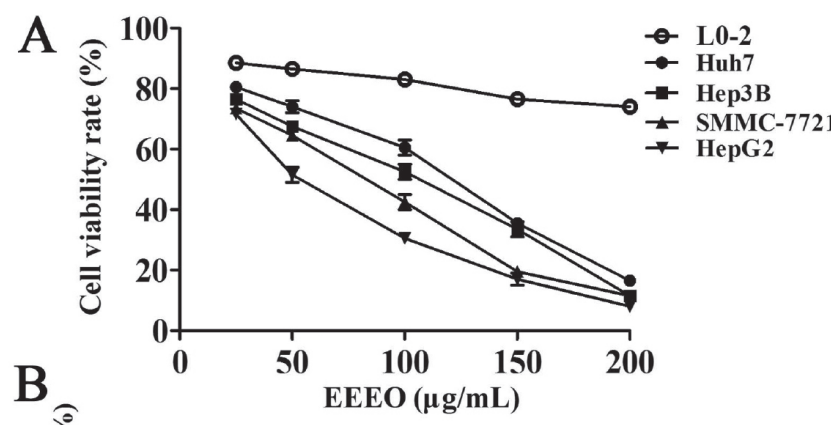

\begin{tabular}{cc}
\hline Cell line $(24 \mathrm{~h})$ & $\mathrm{IC}_{50}(\mu \mathrm{g} / \mathrm{mL})$ \\
\hline Huh7 & 100.70 \\
Hep3B & 82.06 \\
SMMC-7721 & 66.58 \\
HepG2 & 50.67 \\
L0-2 & $>100$ \\
\hline${ }^{\text {a }}$ Normal liver cells originated from human
\end{tabular}
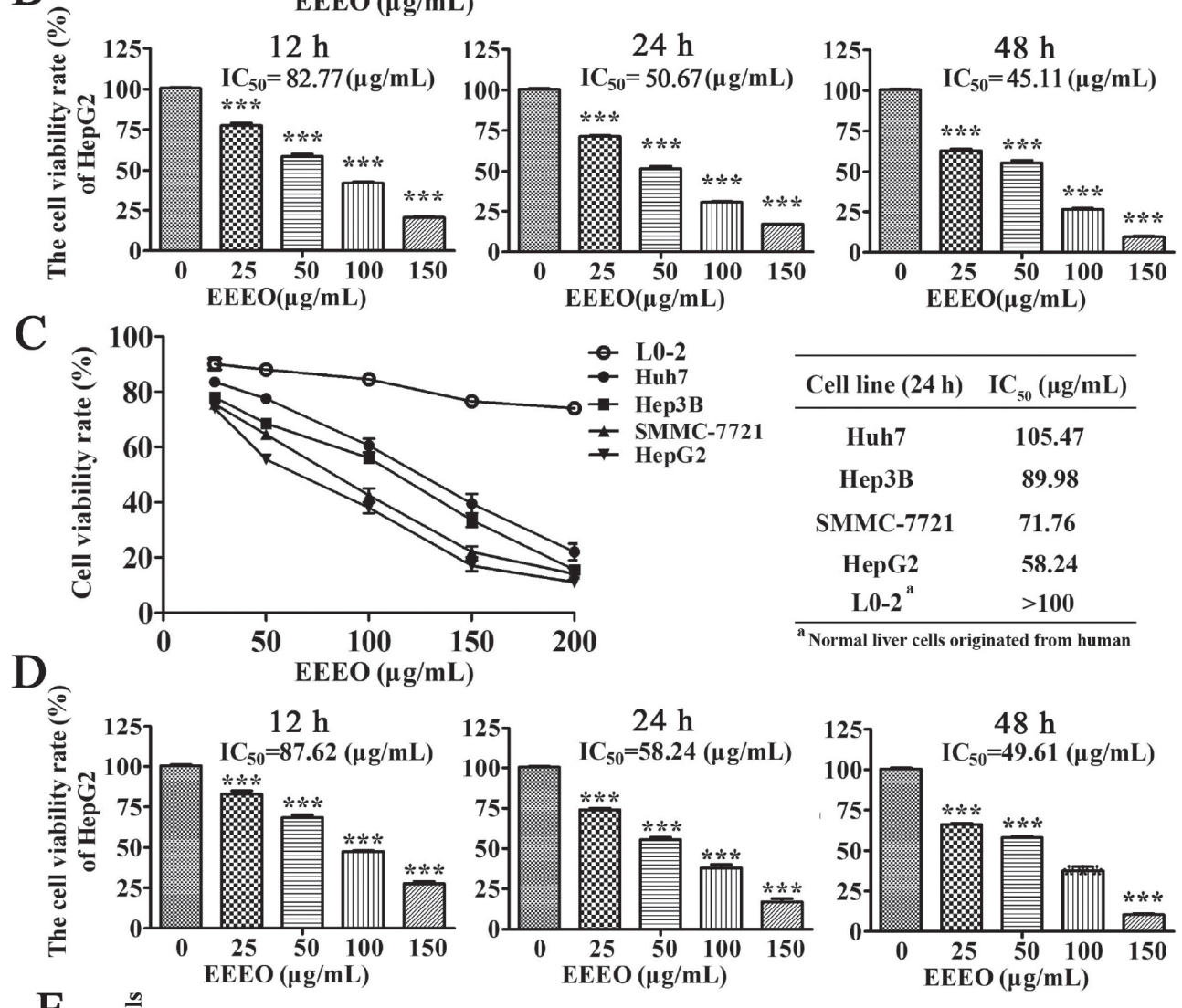

$\operatorname{EEO}(\mu \mathrm{g} / \mathrm{mL})$
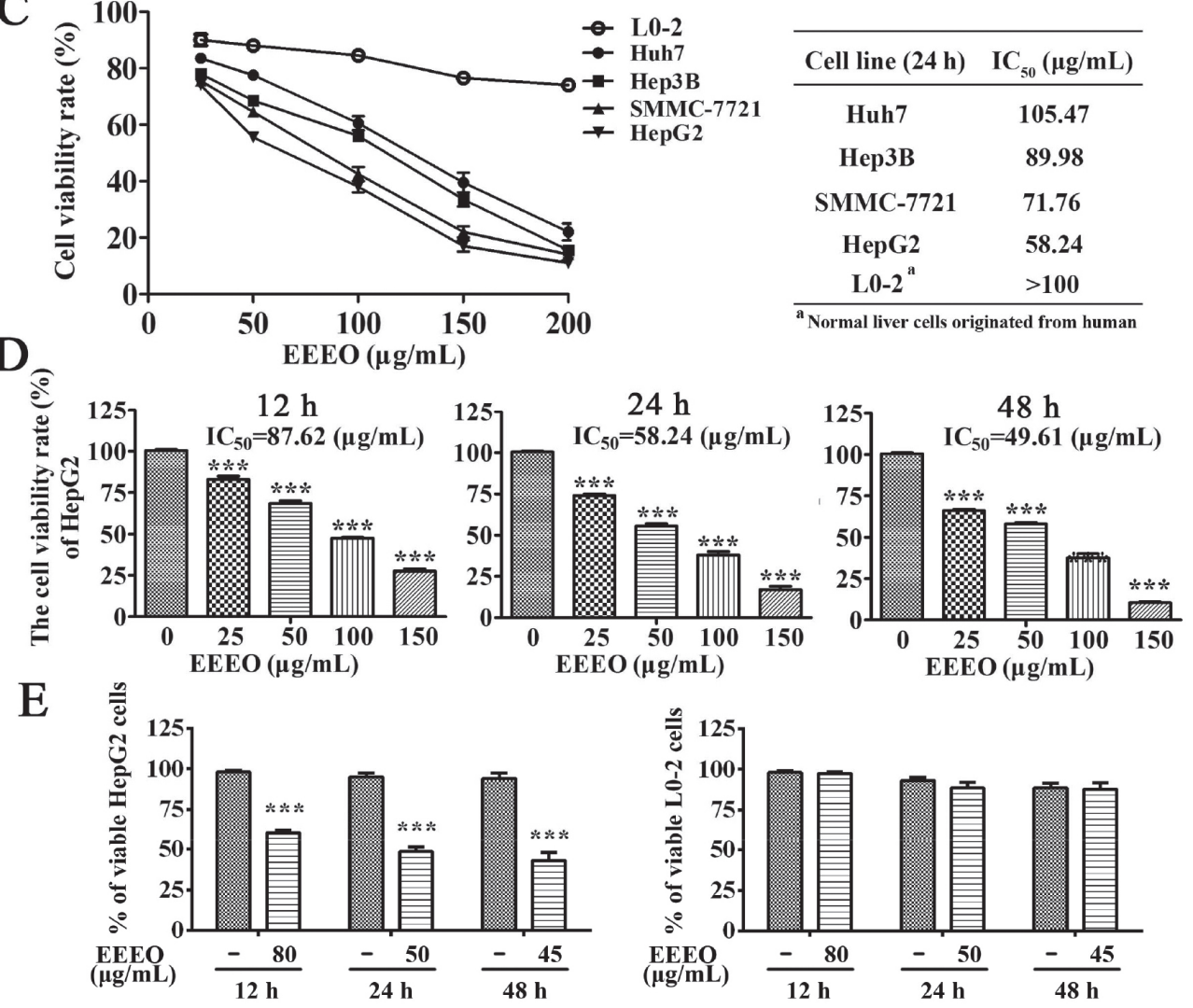

FIGURE 2 - Selective inhibitory effects of EEEO on cells proliferation. (A, B) In MTT assay, EEEO treatment inhibited HCC cells proliferation, but did not induce anti-proliferation in normal liver cells. HepG2 cells showed the most sensitive to EEEO treatment and were inhibited in a time- and dose-dependent manner. Hepatocellular carcinoma cell lines (Huh7, Hep3B, SMMC-7721 and HepG2) and normal liver cell line (L0-2) were treated with $0-150 \mu \mathrm{g} / \mathrm{mL}$ of EEEO for $24 \mathrm{~h}$, and $\mathrm{IC}_{50}$ values were calculated by MTT assay. The most sensitive cell line was further tested with above concentrations of EEEO for $12 \mathrm{~h}, 24 \mathrm{~h}$ and $48 \mathrm{~h}$. (C, D) $\mathrm{IC}_{50}$ values were also calculated by CCK-8 assay in above cell lines. Similarly, HepG2 cells were sensitive to EEEO, and showed time and dose-dependent inhibition by EEEO. (E) To verify the anti-proliferative effects and toxicity of EEEO, HepG2 and L0-2 cells were treated with EEEO whose concentrations were approximated with $\mathrm{IC}_{50}$ values, and trypan blue exclusion staining was performed to measure the percentage of viable cells. In above assay, $0 \mu \mathrm{g} / \mathrm{mL}$ (or labeled as -) of EEEO served as control group. The data is shown as the means $\pm \mathrm{SD}$ from three independent experiments. Asterisk denote a response that is significantly different from the control $(* * * P<0.001)$. 
A

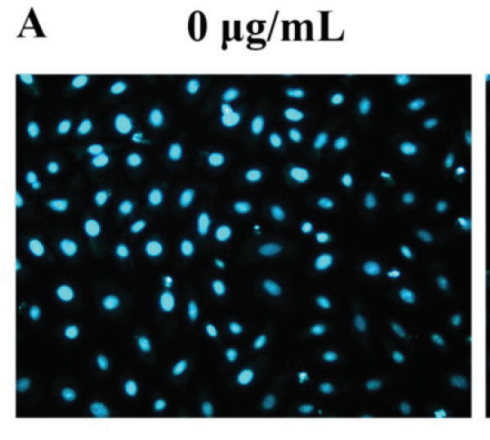

B

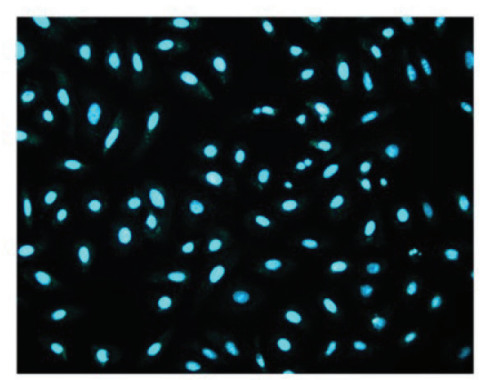

C
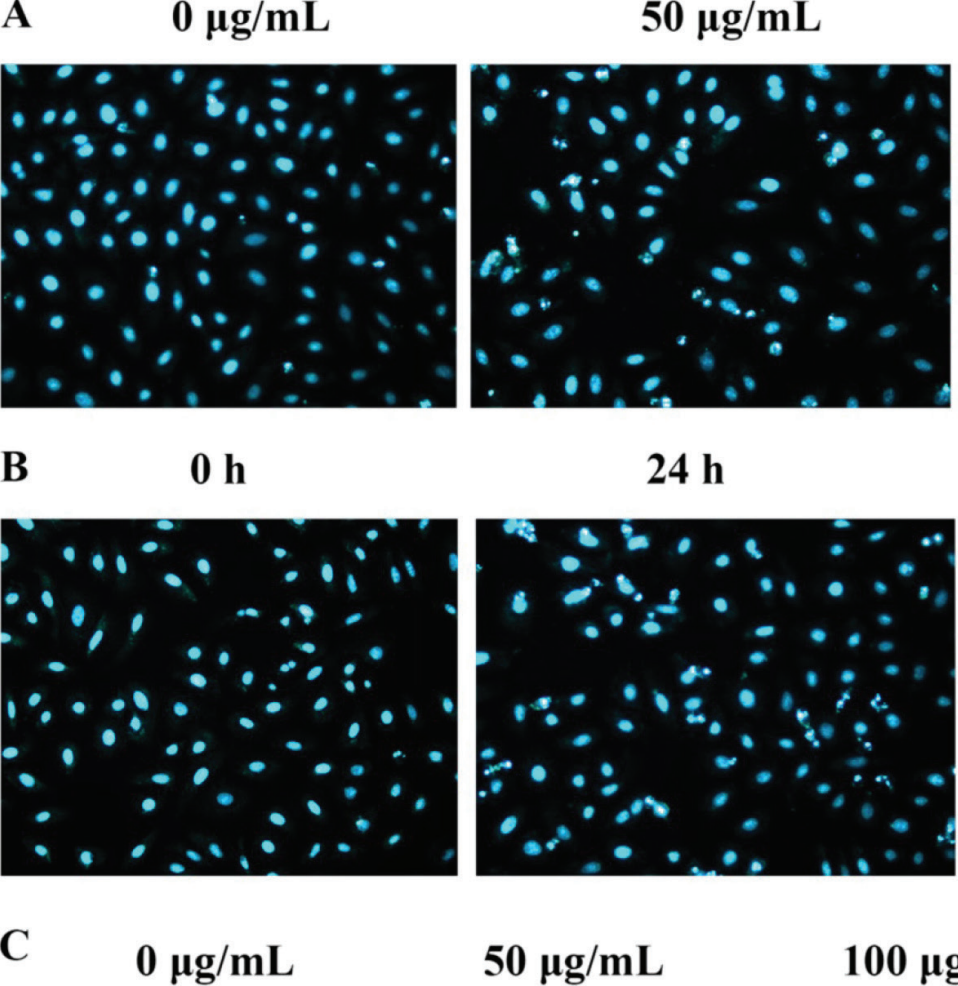

$24 \mathrm{~h}$

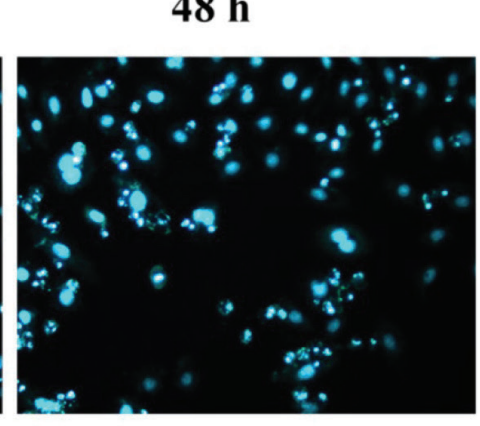

$48 \mathrm{~h}$
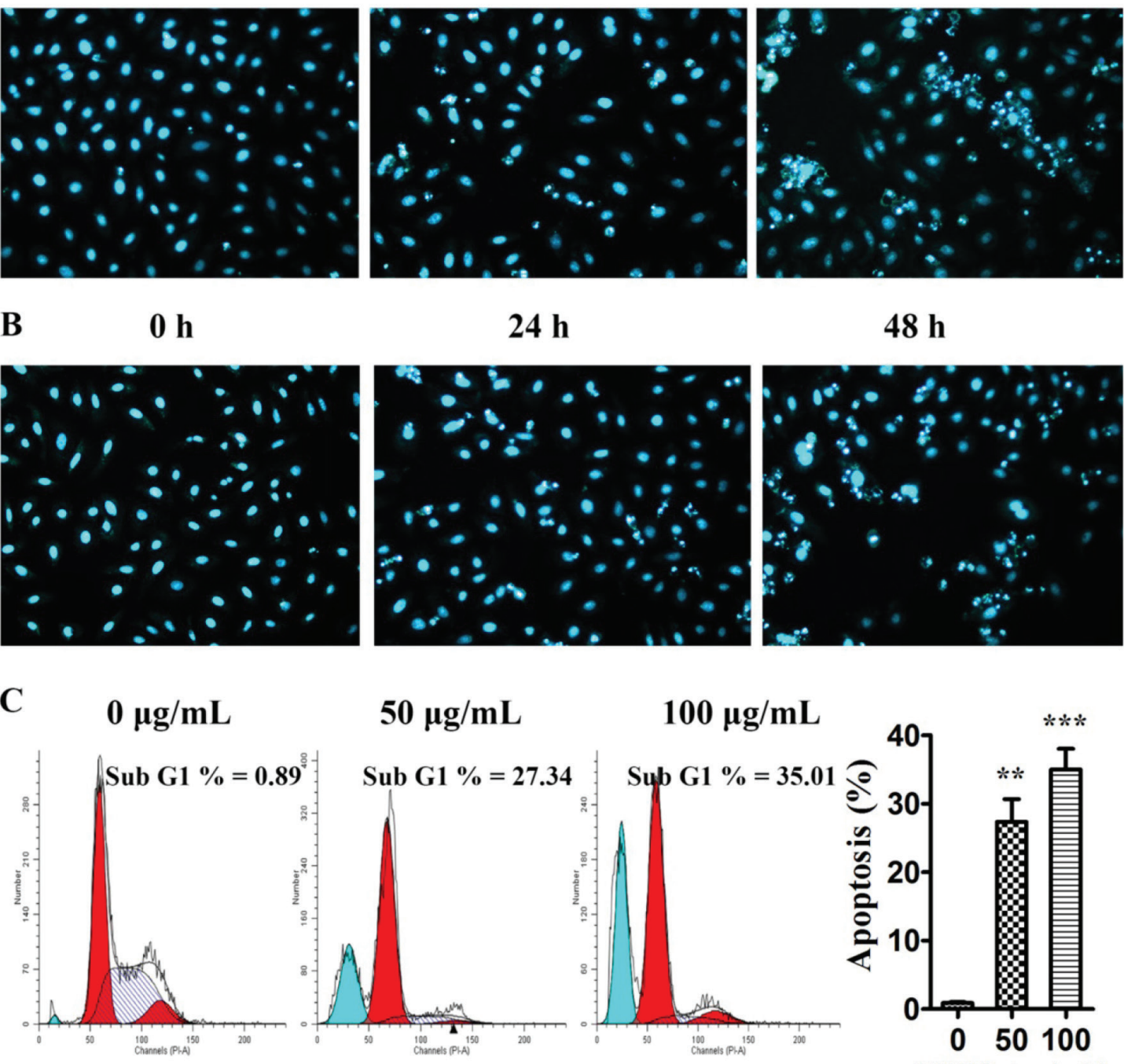

D

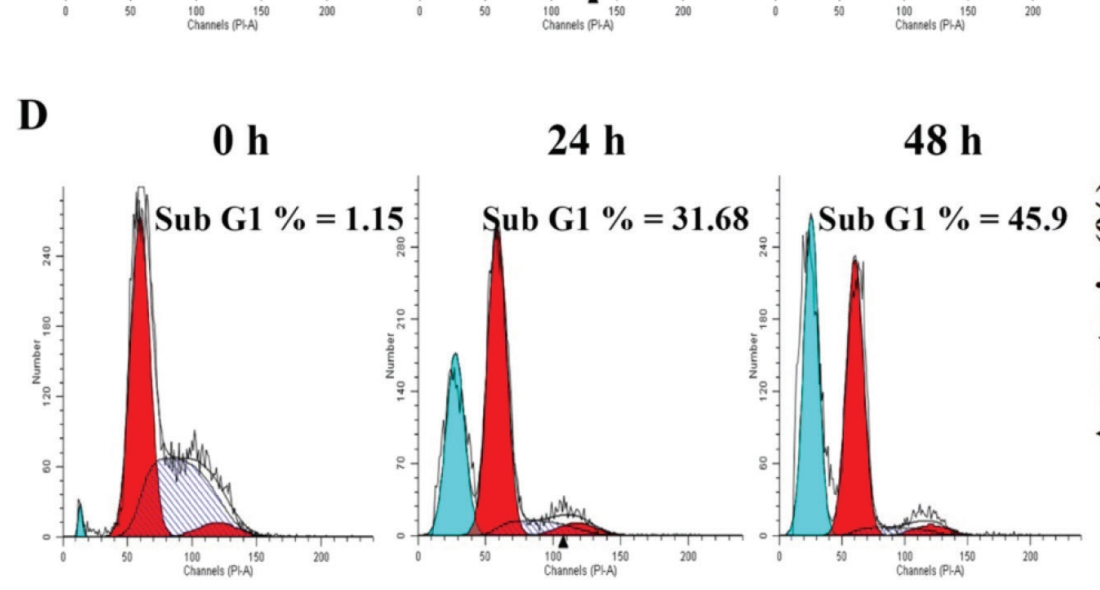

$100 \mu \mathrm{g} / \mathrm{mL}$
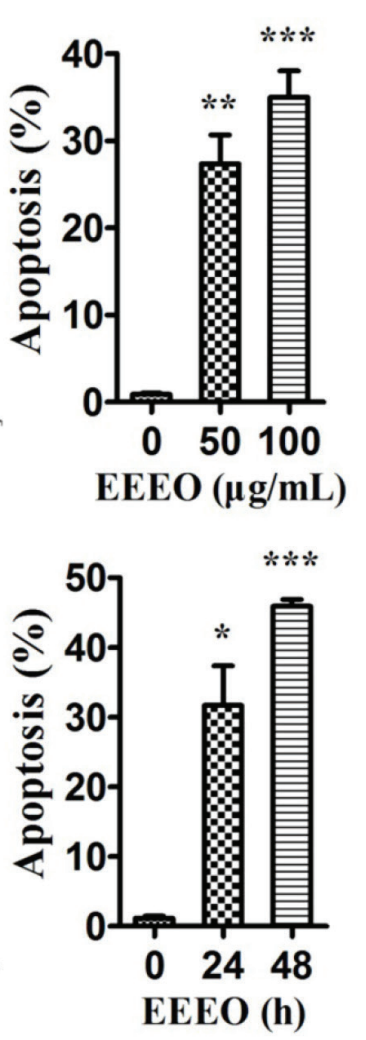

FIGURE 3 - EEEO dose- and time- dependently provoked human HepG2 cell apoptosis in vitro. (A) HepG2 cells were treated with 0,50 and $100 \mu \mathrm{g} / \mathrm{mL}$ of EEEO. After $24 \mathrm{~h}$, cell was observed under phase contrast microscope. (B) As time grows ( 0,24 and $48 \mathrm{~h}$ ), cells were also observed under phase contrast microscope ( $50 \mu \mathrm{g} / \mathrm{mL}$ of EEEO). (C) HepG2 cells were treated with 0,50 and $100 \mu \mathrm{g} / \mathrm{mL}$ of EEEO for $24 \mathrm{~h}$. Then, cell apoptosis was observed by FASC. (D) HepG2 cells were treated with $100 \mu \mathrm{g} / \mathrm{mL}$ EEEO for 0,24 and $48 \mathrm{~h}$ times. Then, cell apoptosis was examined by FACS. $0 \mu \mathrm{g} / \mathrm{mL}$ ( or $0 \mathrm{~h}$ ) of EEEO treatment served as control group. The data are shown as the means \pm SD from three independent experiments. $* P<0.05$, $* * P<0.01$ and $* * * P<0.001$ vs. control. Results are representative of three independent tests. 
A

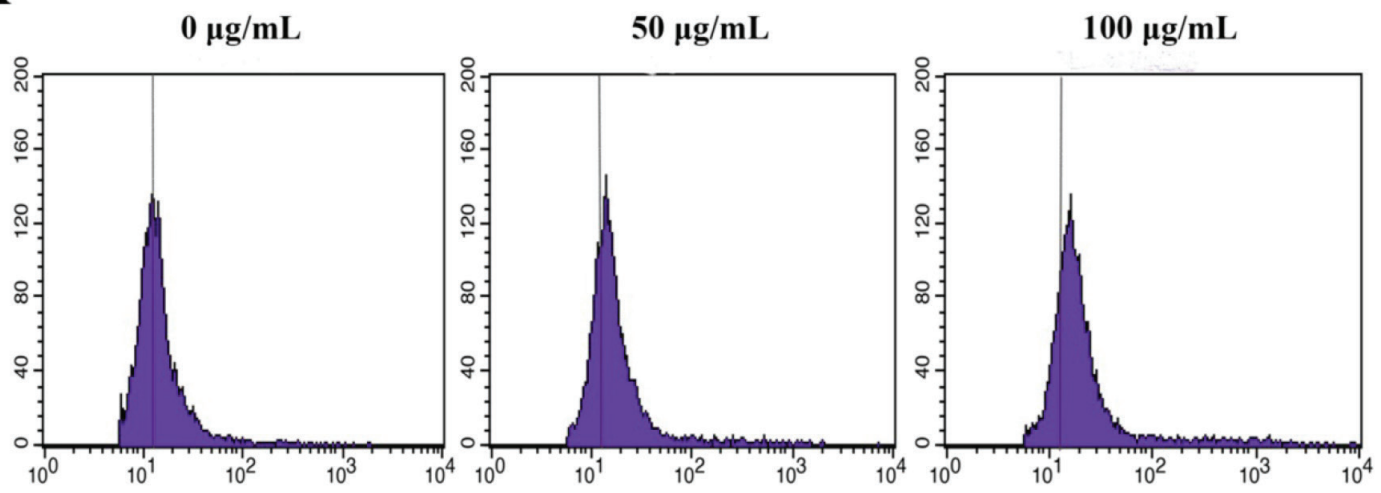

B

$\mathbf{0 ~ h}$

$12 \mathrm{~h}$

$24 \mathrm{~h}$
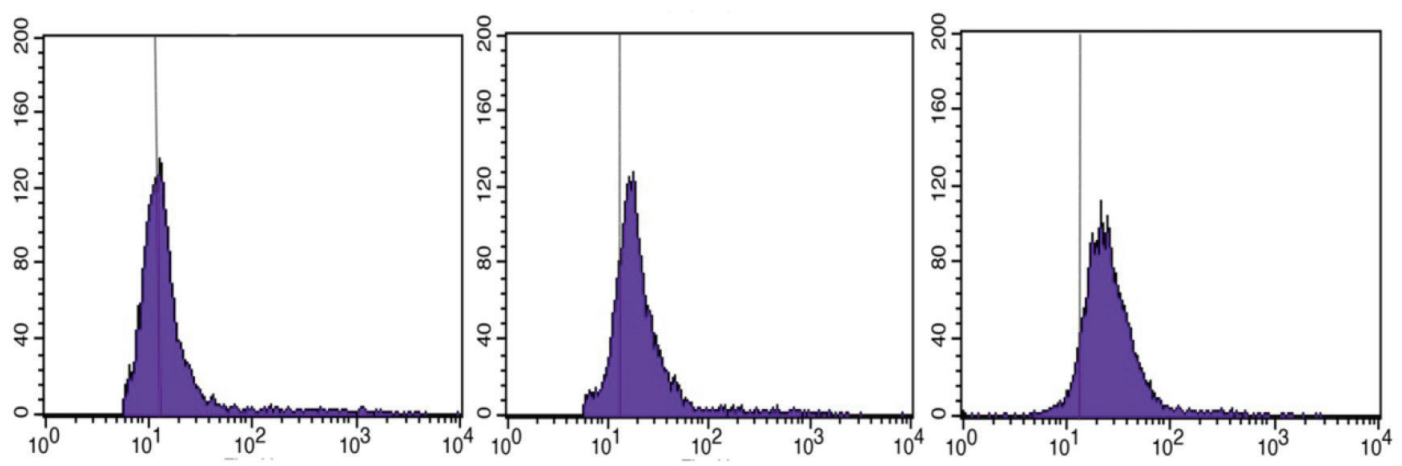

FIGURE 4 - The changes in the accumulation of ROS. (A) EEEO induced increase of ROS in dose-dependent manners. (B) HepG2 cells were treated with $50 \mu \mathrm{g} / \mathrm{mL}$ EEEO for $0 \mathrm{~h}, 12 \mathrm{~h}$ and $24 \mathrm{~h}$.

A
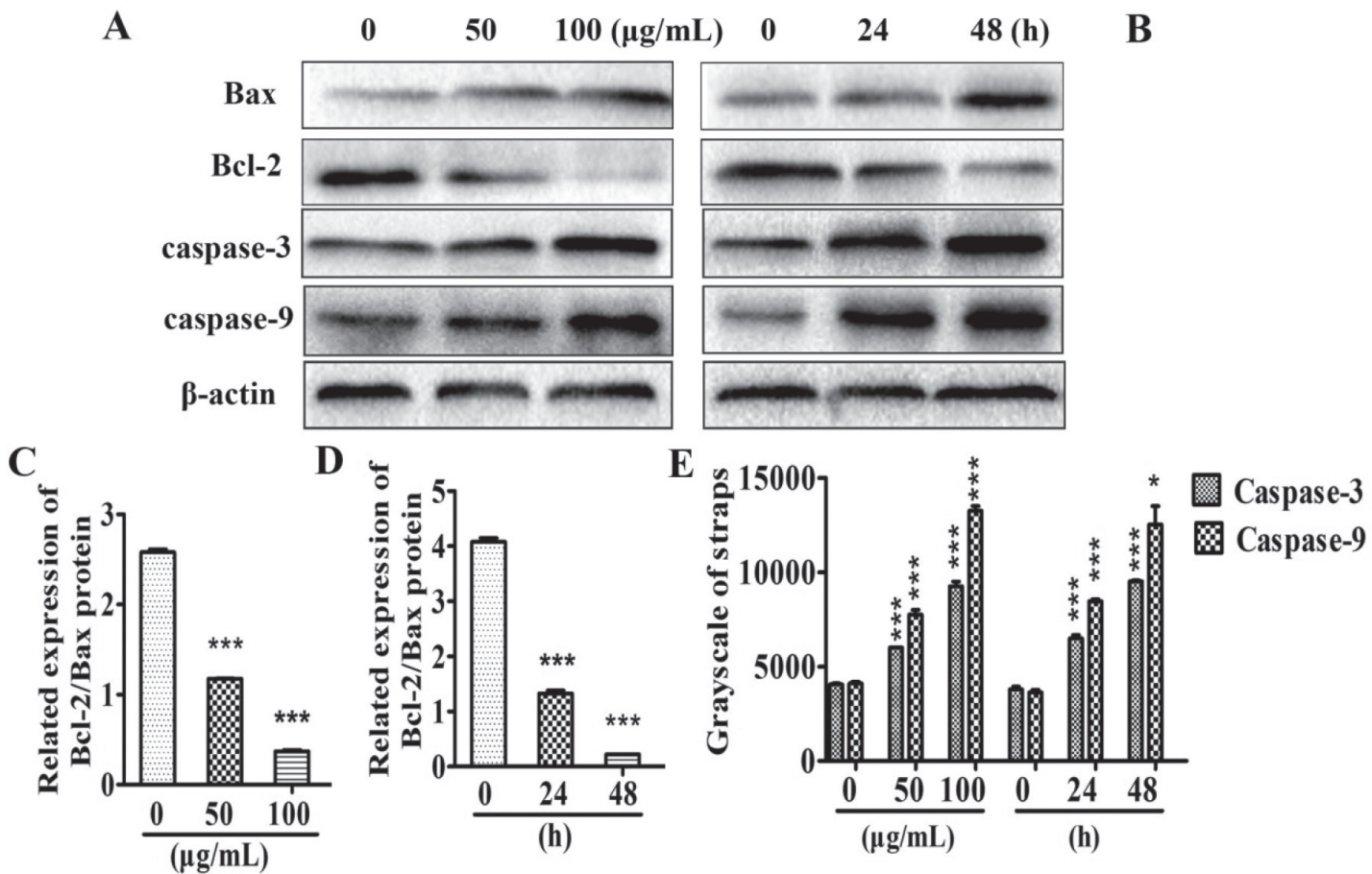

FIGURE 5 - (A) HepG2 cells were cultivated with 0,50 and $100 \mu \mathrm{g} / \mathrm{mL}$ of EEEO for $24 \mathrm{~h}$, and (B) incubated for 0,24 and $48 \mathrm{~h}$ with $50 \mu \mathrm{g} / \mathrm{mL}$ of EEEO, respectively. And then Bax, Bcl-2, caspase-3, caspase- 9 and $\beta$-actin were assessed via Western blotting. (C, D) Bcl-2/Bax ratio and (E) quantification of caspase- 3 and caspase- 9 were analyzed and expressed. $0 \mu \mathrm{g} / \mathrm{mL}$ (or $0 \mathrm{~h}$ ) of EEEO treatment served as control group. Statistical analysis was tested at significance $* P<0.05$ and $* * * P<0.001$ compared to untreated control. 
then triggers executioner caspase-3, leading to apoptosis. Collectively, these data showed that EEEO could activate the expression of caspase-3 and caspase-9 and downregulate $\mathrm{Bcl}-2 / \mathrm{Bax}$ expression, leading to apoptosis in HepG2 cells mediated by the mitochondrial-dependent pathway.

\section{DISCUSSION}

Since the beginning of the century, the exploration and research of natural medicine has increased in popularity (Bauer, Brönstrup, 2014). Chinese herbal medicines are rich in natural resources consisting of beneficial components with diverse chemical structures, a wide anticancer spectrum with little side effects, and low developmental costs (Ergil, Kramer, Ng, 2002). It has continued to receive domestic and foreign medical attention. Looking for effective components in natural products to treat diseases tends to become international.

The present study has shown that an essential oil extract from E. esula (EEEO), considered as a Chinese herbal medicine, induced hepatocyte apoptosis in a liver cancer cell line (Whelan, Ryan, 2003). However, the potential anti-cancer mechanism of E. esula is not fully understood. This study examined the cell viability of EEEO in HepG 2 cell line by MTT assay, CCK-8 assay, trypan blue exclusion test and Hoechst33528 staining. The results showed that EEEO selectively inhibited proliferation of HepG2 cells in a time- and dose-dependent manner without observable toxicity on normal liver cells. As an important mechanism mediating cell death, apoptosis is well known to be involved in the process of HCC. Consequently, cell cycle analysis indicated that EEEO arrested cell cycle at the G0/G1 transition and induced HepG2 cell apoptosis.

Acting as signaling molecules, ROS plays a key role in physiological processes, including host defense, aging, and cellular homeostasis (Ray, Huang, Tsuji, 2012). Several studies to date have suggested that novel therapeutic strategies can be developed to preferentially inhibit cancer cell growth by increasing ROS generation. For example, the drug tempol suppresses growth of existing tumors by inhibiting proliferation and inducing apoptosis (Han, Park, 2012). In the present study, we found that EEEO significantly increased ROS levels in dosedependent manner, revealing that ROS may be related to the apoptosis in HepG2 cells induced by EEEO.

Apoptosis can be initiated via 2 alternative signaling pathways: the mitochondrial-mediated intrinsic apoptotic pathway and the death receptor-mediated extrinsic apoptotic pathway (Lin et al., 2008). Mitochondrial apoptosis pathways can be initiated by intracellular stimuli and by the Bcl-2 family proteins that act as sensors to integrate death and survival signals (Yang et al., 2015). The ratio of $\mathrm{Bcl}-2 / \mathrm{Bax}$ is a pivotal determinant, and its reduction leads to an increase in mitochondrial outer membrane permeabilization, which in turn leads to the activation of caspase- 3 and caspase-9, finally triggering activation of caspase cascades culminating in cellular fragmentation (Zhao et al., 2015). E. esula extract has been reported to inhibit proliferation and induce apoptosis in SGC-7901 cells, in a caspasedependent manner, involving upregulation of Bax and downregulation of Bcl-2 (Fu et al., 2016). To determine which apoptosis-related proteins are regulated by EEEO in HepG2, the expression of Bax, Bcl-2, Caspase-3 and Caspase-9 proteins were analyzed using western blotting methods. The data showed that EEEO down-regulated Bcl-2/Bax protein ratio in HepG2 cells suggesting that EEEO promoted apoptosis of HepG2 cells. It is likely that the decrease in $\mathrm{Bcl}-2 / \mathrm{Bax}$ protein ratio could induce caspase-dependent mitochondrial apoptosis.

\section{ACKNOWLEDGMENTS}

We thank Accdon and Dr. Mohammad Omar Faruque for the linguistic assistance during the preparation of this manuscript.

\section{CONFLICT OF INTEREST STATEMENT}

The authors declare no competing interests.

\section{SUPPORT}

This project was financially supported by the Talent Introduction Project of Hangzhou Medical College, Zhejiang Province, China (No.2015B08), the Natural Science Foundation of Hubei Province of China (No.2017CFB517), Open Project Fund of Hubei Province Key Laboratory of Occupational Hazard Identification and Control (No. OHIC2017G03) and National Natural Science Foundation of China grants (No. 81573561 and No. 81573239).

\section{REFERENCES}

Banafa A M, Roshan S. Fucoidan induces G1 phase arrest and apoptosis through caspases-dependent pathway and ROS induction in human breast cancer MCF-7 cells. J Huazhong Univ Sci Technol Med Sci. 2013;33(5):717-724. 
Bauer A, Brönstrup M. Industrial natural product chemistry for drug discovery and development. Nat Prod Rep. 2014;31(1):3560 .

Chen SL, Gilbert MG. Flora of China. Science, Beijing and Missouri Botanical Garden Press, St Louis; 2006.

Ernst M, Grace OM, Saslis-Lagoudakis CH, Nilsson N, Simonsen HT, Rønsted N, et al. Global medicinal uses of Euphorbia L. (Euphorbiaceae). J Ethnopharmacol. 2015;176:90101.

Ergil KV, Kramer EJ, Ng AT. Chinese herbal medicines. Western J Med. 2002;176(4):275-279.

Feng X, Yu W, Zhou F, Chen J, Shen P. A novel small molecule compound diaporine inhibits breast cancer cell proliferation via promoting ROS generation. Biomed Pharmacother. 2016;83:1038-1047.

Fu Z Y, Han XD, Wang AH, Liu XB. Apoptosis of human gastric carcinoma cells induced by Euphorbia esula latex. World J Gastroenterol. 2016;22(13):3564-3572.

Hong YP, Li ZD, Prasoon P, Zhang Q. Immunotherapy for hepatocellular carcinoma: From basic research to clinical use. World J Hepatol. 2015;7(7):980-992.

Huang J, Zhou C, He J, Hu Z, Guan WC, Liu SH. Protective effect of reduced glutathione C60. J Huazhong Univ Sci Technol Med Sci. 2016;36(3):356-363.

Han YH, Park WH. Tempol inhibits growth of As4.1 juxtaglomerular cells via cell cycle arrest and apoptosis. Oncol Rep. 2012;27(3):842-848.

Li XQ, Ling CQ. Chinese herbal medicine for side effects of transarterial chemoembolization in liver cancer patients: a systematic review and meta-analysis. Chin J Integr Med. 2012;10(12):1341-1362.

Li Y, Liu B, Yang F, Yu Y, Zeng A, Ye T, et al. Lobaplatin induces BGC-823 human gastric carcinoma cell apoptosis via ROSmitochondrial apoptotic pathway and impairs cell migration and invasion. Biomed Pharmacother. 2016;83:1239-1246.

Liu B, Lei M, Hu T, Yu F, Xiao DM, Kang H. Inhibitory effects of SRT1720 on the apoptosis of rabbit chondrocytes by activating SIRT1 via $\mathrm{p} 53 / \mathrm{bax}$ and $\mathrm{NF}-\kappa \mathrm{B} / \mathrm{PGC}-1 \alpha$ pathways. J Huazhong Univ Sci Technol Med Sci. 2016;36(3):350-355.
Lin Y, Shi R, Wang X, Shen HM. Luteolin, a flavonoid with potential for cancer prevention and therapy. Curr Cancer Drug Targets. 2008;8(7):634-646.

Lv D, Guo KW, Xu C, Huang M, Zheng SJ, Ma XH, et al. Essential oil from Siegesbeckia pubescens induces apoptosis through the mitochondrial pathway in human HepG2 Cells. J Huazhong Univ Sci Technol Med Sci. 2017;37(1):87-92.

Mi Y, Xiao C, Du Q, Wu W, Qi G, Liu X. Momordin Ic couples apoptosis with autophagy in human hepatoblastoma cancer cells by reactive oxygen species (ROS)-mediated PI3K/ Akt and MAPK signaling pathways. Free Radical Bio Med. 2016;90:230-242.

Ray PD, Huang BW, Tsuji Y. Reactive oxygen species (ROS) homeostasis and redox regulation in cellular signaling. Cell Signal. 2012;24(5):981-990.

Santos MS, Abreu PH, García-Laencina PJ, Simão A, Carvalho A. A new cluster-based oversampling method for improving survival prediction of hepatocellular carcinoma patients. J Biomed Inform. 2015;58:49-59.

Song P, Xu C, Ma YR, Lv J, Yang J, Wang C, Yang X. In vitro anti-hepatoma screening of 100 commonly used Tibetan medicines. J South Central Univ National (Nat Sci Edition). 2015a;34(2):64-67.

Song P, Wang Q, Lv J, Xu C, Lin QX, Ma XH, et al. HPLC-based activity profiling of anti-hepatocellular carcinoma constituents from the Tibetan medicine, Caragana tibetica. J Huazhong Univ Sci Technol Med Sci. 2015b;35(3):450-455.

Stepanenko AA, Dmitrenko VV. Pitfalls of the MTT assay: direct and off-target effects of inhibitors can result in over/ underestimation of cell viability. Gene. 2015;574(2):193-203.

Wei KR, Yu X, Zheng RS, Peng X-B, Zhang S-W, Ji M-F, et al. Incidence and mortality of liver cancer in China, 2010. Chin J Cancer. 2014;33(8):388-94.

Whelan LC, Ryan MF. Ethanolic extracts of Euphorbia and other ethnobotanical species as inhibitors of human tumor cell growth. Phytomedicine. 2003;10(1):53-58.

Xu M, Hong M, Xie H. Histone deacetylase inhibitors induce human renal cell carcinoma cell apoptosis through p-JNK activation. J South Med Univ. 2013;33(10):1409-1415. 
Yang X, Huang M, Zheng S, Ma X, Wan D, Feng Y, et al. Liquid chromatography with mass spectrometry and NMR spectroscopy based discovery of cytotoxic principles from Daphne tangutica Maxim. J Sep Sci. 2016;39(11):2179-2187.

Yang X, Huang M, Cai J, Lv D, Lv J, Zheng S, et al. Chemical profiling of anti-hepatocellular carcinoma constituents from Caragana tangutica Maxim. by off-line semi-preparative HPLCNMR. Nat Prod Res. 2017;31(10):1150-1155.

Yang L, Cui Y, Shen J, Lin F, Wang X, Long M, et al. Antitumor activity of SA12, a novel peptide, on SKBr-3 breast cancer cells via the mitochondrial apoptosis pathway. Drug Des Dev Ther. 2015;9:1319-1330.
Zheng Q, Liu W, Li B, Chen HJ, Zhu WS, Yang GX, et al. Anticancer effect of icaritin on human lung cancer cells through inducing S phase cell cycle arrest and apoptosis. J Huazhong Univ Sci Technol Med Sci. 2014;34(4):497-503.

Zhao W, Yang Y, Zhang YX, Zhou C, Li HM, Tang YL, et al. Fluoride-containing podophyllum derivatives exhibit antitumor activities through enhancing mitochondrial apoptosis pathway by increasing the expression of caspase-9 in HeLa cells. Sci Rep. 2015;5:17175.

Received for publication on $17^{\text {th }}$ September 2017 Accepted for publication on $17^{\text {th }}$ October 2018 